\title{
Revisiting the Religious Violence Thesis: Minorities in the Middle East
}

Paper presented at the 2019 American Political Science Association Annual Meeting

\author{
August 17, 2019 \\ Günes Murat Tezcür (tezcur@ucf.edu) \\ Jalal Talabani Chair and Professor \\ School of Politics, Security, and International Affairs \\ University of Central Florida
}

\begin{abstract}
Why do ordinary individuals participate in political campaigns involving mass looting, killings, and enslavement against members of another religious group? This paper addresses this question by highlighting the role of religious beliefs perceived to be sanctioned by God in overcoming human aversion to physically harming humans. It argues that religious justifications of violence have a stronger appeal when they target liminal minorities whose beliefs and norms remain illegible in the eyes of a majority religion. It then formulates a series of alternative hypotheses about the role of greed, threat, resentment, and guilt in the motives of perpetrators and uses the self-styled Islamic State (IS) campaign against Yezidis in 2014 as a case study to test these hypotheses. Empirical evidence comes from extensive fieldwork including dozens of in-depth interviews with Yezidi survivors and others in Iraqi Kurdistan. The analysis reveals that religious beliefs were necessary both for making extreme levels of violence permissible and for mobilizing local population to participate in the atrocities.
\end{abstract}

The author gratefully acknowledges funding support from the Global Religion Research Initiative of Notre Dame University and University of Central Florida (UCF) Foundation. The fieldwork received Human Subjects approval from UCF Institutional Review Board (SBE-18-13819). Tutku Ayhan provided outstanding research assistance. 


\section{Introduction}

In “The Third of May 1808," Francisco Goya depicts a group of Spanish rebels who are being executed by an invading French army. The contrast between the agonized victims and the faceless and emotionless firing squad evokes deep sympathy for the former. The influence of Goya is apparent in both Édouard Manet's "Execution of Emperor Maximilian (1868-9)" and Pablo Picasso's “Massacre in Korea.” Despite vast stylistic and contextual differences, the humanity of the condemned makes the executioners, a relentless force acting in cold blood, terrifying. Given this powerful artistic tradition, the Iranian photographer Jahangir Razmi's "Firing Squad in Iran" provides an alternative representation of the act of killing. His photo captures the moment when a ragtag group of revolutionary soldiers executed blindfolded Kurdish rebels in Iran in 1979. The killers lack the aura of unstoppable and efficient force as depicted by Goya, Manet, or Picasso. The bifurcated image of the act of killing and being killed dissipates in the photography of Razmi that suggests that the act of killing can be cruel in an intimate and mundane ways.

This article deals with these intimate and mundane ways of political violence. It focuses on the participation of ordinary individuals in large scale massacres against members of another religious group. By doing so, it directly engages in the debate over the notion of "religious violence" and examines how and why religious beliefs inform the motives of perpetrators of violence. There is much skepticism about the argument that religion uniquely contributes to violence. What is often depicted as a "religious conflict" may be caused by social, economic and (geo)political dynamics (e.g., Cavanaugh 2009; Midlarsky 2019). At the same time, religious beliefs perceived to be sanctioned by God could provide a uniquely strong justification of violence (Bushman et al. 2007; Haidt 2012; Norenzayan 2013; Fiske \& Rei 2014; Atran et al. 2017). Such justifications play a crucial role in overcoming human aversion to physically harming others (Grossman 1995). Building on this insight, this paper argues that religious justifications of violence would be have a stronger appeal and less challenged when directed against certain groups more than others. Liminal minorities are groups whose beliefs and norms remain illegible and are perceived to be outside of the moral order of a hegemonic religion (or religions). They are typically perceived as a threat to this moral order and feared as a source of symbolic pollution (Douglas 1966). Consequently, extreme levels of violence against these groups are often more permissible and actable.

The self-styled Islamic State (IS) campaign against Yezidis in 2014 provides an a crucial case study of religious violence and involves two historical puzzles. ${ }^{1}$ First, although

\footnotetext{
${ }^{1}$ The broader project involves a cross-sectional comparative research design comparing Yezidis with Alevis in addition to a general discussion of liminal minorities in the Muslim world and beyond.
} 
the IS left a trail of death and destruction in the areas it occupied; its treatment of Yezidis qua Yezidis was disproportionately vicious. While the IS targeted other religious minorities in the Nineveh governorate in northern Iraq; it only executed, kidnapped, enslaved, and forcefully converted Yezidis in large numbers (OHCHR 2016; Simon-Skjodt Center for the Prevention of Genocide 2015). What explains this exceptional nature of the anti-Yezidi violence? Next, local Sunni Muslims actively took part in the atrocities against Yezidis. Not only did they participate in mass lootings and shootings, but also enslaved Yezidi women and children for an extended period. Most strikingly, many of these local collaborators had personal relations with Yezidis. What explains the motivation of ordinary people to participate in violence?

It is empirically feasible to distinguish among religious and non-religious motives of perpetrators and isolate the effects of the former by adopting a micro-level research design. The paper formulates a series of hypotheses about the role of (religious) hatred, greed, threat, resentment, and guilt in the motives of perpetrators (i.e., the IS and local collaborators). While religion may not be sufficient to cause violence by itself, certain violent patterns "cannot without the doctrinal templates and rhetorical justifications of religion (Grzymala-Busse 2016, p. 347). Accordingly, the paper employs a series of hoop tests to identify motives that are necessary conditions for violence to happen (Collier 2011).

The empirical analyses show no evidence for the threat and guilt and limited evidence for the greed and resentment hypotheses. The strongest evidence is available for the religious hatred argument. Neither the IS's exceptionally vicious treatment of Yezidis nor the participation of local people in these atrocities could be fully understood without highlighting how religious beliefs at both ideological and popular levels provided unique justifications for such violence. While this stigmatization has its historical roots in orthodox Islam, its dissemination at the local level is a more modern phenomenon.

The article is based on extensive fieldwork involving dozens of in-depth interviews with a variety of individuals including Yezidi leaders and displaced survivors, local and international activists, and Iraqi Kurdish officials involved in Yezidi affairs. The fieldwork took place in several locations including Iraqi Kurdistan (September 2017 and May-June 2018) and Germany (June 2017). ${ }^{2}$ It also involves extensive analyses of historical and contemporary documents about the perception of Yezidis by non-Yezidi communities and ruling authorities.

\footnotetext{
${ }^{2}$ Some of the interviews were conducted by Tutku Ayhan, a doctoral candidate at UCF. A partial list of interviews is provided in Appendix.
} 


\section{Religious Violence \& Liminal Minorities}

I define religious violence as physical harm committed against members of a group and motivated by their perceived deviance from or defiance of a system of beliefs in a supernatural being (i.e., God) that rules over physical forces. This definition has two core characteristics. First, religion is primarily about humans' exchanges with God to obtain otherworldly rewards (Stark and Finke 2000, pp. 91-9). Next, what matters is the motives guiding the act of violence. This is distinct from both issue-oriented and identity-oriented approaches to religious violence. According to the issue-oriented approach (e.g., Fox 2004), a violent conflict has religious characteristics as long as opposing groups have different religious affiliations (e.g., Catholics versus Protestants in Northern Ireland, Sunnis versus Shiites in Iraq, Muslims versus Buddhists in Myanmar). While this approach significantly expands the universe of religious conflict, it is also highly vulnerable to conceptual overstretching. While religious markers could differentiate between opposing sides, conflict could be about socioeconomic and political factors completely unrelated to religious belief systems. In contrast, the issue-oriented approach focuses on conflicts characterized by competing religious claims over topics. A prominent example is the question of control over the Jerusalem's Holy Esplanade that is sacred to both Islam and Judaism. From this perspective, the inherent incompatibility of exclusive control by either side (e.g., Israel versus Palestinians and Muslim states) contributes to the intensity of a conflict (Hassner 2009). In fact, there has been a significant increase in "religious issue conflicts" while there has been a decline in "non-religious issue conflicts" between groups with different religious identities (Svennson and Nilson 2018, p. 1139).

Religious claims about issues at stake (e.g., arguing that spatial control is non-negotiable given its sacred nature) do not necessarily mean that opposing groups have primarily religious motives. In fact, there is a long tradition of skepticism about treating religion as a cause of mass scale violence. Religious rhetoric and discourse could be figleafs hiding economic interests and power politics. In his study of peasant rebellions in Germany in the 16th century, Engels (1926, p. 27) writes, "those wars were class wars just as were the later collisions in England and France...if the interests, requirements and demands of the various classes hid themselves behind a religious screen, it little changes the actual situation." Cavanaugh (2009, p. 177) similarly suggests that it is analytically impossible to separate religious motives from social, economic and political causes of violent conflict in his review of "the so-called religious wars" of the early modern Europe. He refutes the argument that religion "is necessarily more inclined toward violence than are ideologies and institutions that are identified as secular (p. 5)." For him, there is nothing in religion that 
makes it uniquely prone to or causes violence. Accordingly, scholars studying ethnic conflict often treat religion as one of multiple identity markers that could become the basis of violent mobilization. In this regard, religion is not substantively different than language, tribe, geographical origin, caste, clan, or race (Chandra 2006). Brubaker (2015:12) argues that while religion can foster violence via at least six mechanisms, none of those are intrinsic to religion itself. State elites pursuing nationalistic ideologies were often the main actors planning and undertaking mass killings of members of a particular group in modern times (Weitz 2003). These campaigns did not necessarily rely on religious justifications even when they targeted members of another religion (Suny 2015). Moreover, the struggle over land was a dynamic central to the logic of ethnic cleansing and mass violence (Toft 2003; Mann 2005; Hayden 2006). Besides, from a historical perspective, the advent of modernity associated with the rise of colonial practices reifying and politicizing ethnic differences (Mamdani 2001; Lange 2017) and the struggle over the control of the state among ethnic groups (Wimmer 2013) contributed to spikes in political violence. Finally, acts of political sacrifice on behalf of a non-religious group has been a common feature of long-lasting ethnonationalist struggles (Tezcür 2016).

This scholarly skepticism is an effective antidote against popular perceptions interpreting armed conflict between groups with distinctive religious identities as a reflection of centuries-old lingering animosities. ${ }^{3}$ Nonetheless, there are also strong reasons to argue that religious beliefs can provide exceptionally strong justifications against groups perceived to fall outside one's moral order. Groups with belief in supernatural omnipotent beings tend to exhibit higher levels of prosocial behavior that give them an evolutionary advantage over rival groups (Haidt 2012, pp. 298-306; Norenzayan 2013, p. 143). As members of these groups believe that their actions are monitored by a supernatural being who can dispense otherworldly benefits, they tend to be more cooperative with and loyal to other group members to receive these benefits. At the same time, they distrust members of out-groups. Consequently, religion by fostering solidarity among believers and hostility against non-believers, is conducive to both parochial altruism (Sapolsky 2017, pp. 621-6; Choi and Bowles 2007; Bowles 2008) and altruistic punishment (i.e., believers harm non-believers at a personal cost to themselves) (Fehr and Gächter 2002). In this regard, religious belief can play a decisive role in overcoming humans' strong emotional inhibitions against

\footnotetext{
${ }^{3}$ In particular, a common view perceives violence in post-2003 Iraq as an inevitable consequence of long repressed ethnic and religious divisions. "Democratization" as introduced by the US was a strategic mistake because it contributed to the rise of sectarian politicians stoking "historical grievances, and exploiting group fear and anger (Chua 2018: 97). This interpretation conveniently overlooks intra-sectarian divisions and a key aspect of democratization, mechanisms of power-sharing, which were not part of the US democratization efforts.
} 
premeditated violence (Grossman 1995; Greene 2014, pp. 36-7, 225-253). Religious beliefs with their promise of otherworldly salvation may also motivate individuals to target groups of "unbelievers" at a significant personal cost (Horowitz 2009; Toft 2013) and forgo compromise in pursuit of a higher good (Juergensmeyer 2009).

Consistent with this perspective, an increasing number of experimental studies show religion fosters not only prosociality but also aggression and biases against members of an out-group. Subjects primed by concepts about God acted less selfishly and allocated more money to anonymous strangers, suggesting that belief in supernatural beings watching human actions leads to prosocial behavior (Shariff and Norenzayan 2007). At the same time, priming subjects with religious words led to higher pejorative views of out-groups perceived to violate religious values (Johnson et al. 2012). Additionally, similar priming resulted in higher levels of costly punishment among individuals who had previously donated to a religious organization (McKay et al. 2011). Moreover, individuals situated in a religious context (e.g., churchyard) expressed more negative views of individuals who are not members of that religious group (LaBouff et al. 2012). Most interestingly, individuals exposed to religious (i.e., scriptural) justifications of violence exhibited higher levels of aggressive behavior than individuals exposed to non-religious ones, an effect more pronounced among believers (Bushman et al. 2007). Finally, aggression towards members of religious out-groups perceived to hold alternative beliefs challenging the validity of one's own tend to be higher, especially during times of existential insecurity (Pyszczynski et al. 2006).

These randomized control trials suggests that religious beliefs could foster violence against out-groups members independently from other factors. An important implication is that some out-groups are more likely to be viewed more pejoratively than others given the historical configuration of religious beliefs systems. Very much like nation states (Scott 1998), orthodox religious establishments aim to make other religious groups legible. Minorities whose sets of beliefs remain illegible are more vulnerable to religiously sanctioned violence. I call them these groups whose core belief systems remain ill-defined, lack clarity, and are subject of widespread rumors in the eyes of members of majority as liminal minorities. A common pattern is that liminal minorities are often perceived to have lax sexual morals threatening the gendered moral order (Davis 1959, pp. 57-8). Accordingly, these groups are more vulnerable to certain types of attacks such as sexual violence than other groups. ${ }^{4}$ Religious groups lacking the protected status of "People of the Book" such as

\footnotetext{
${ }^{4}$ In this regard, conceptualizing violence as a multidimensional process is crucial for explaining its causes and dynamics (Gutiérrez-Sanín \& Wood 2017).
} 
Alevis, Bahais, Ahmadiyya, and Yezidis can be considered as liminal minorities from the perspective of Islamic orthodoxy. Religious beliefs demeaning members of liminal minorities could contribute to their dehumanization, an intergroup process that is often identified as a necessary factor in atrocities against other groups (Livingstone 2011). ${ }^{5}$ Accordingly, religious justifications of violence against these groups could be expected to be more readily pervasive and actable than any other group.

Religious Hatred hypothesis: Hatred of a religious out-group is a necessary role in the scope, intensity, and repertoire of violence directed against its members.

\section{Non-Religious Motives of Violence by Ordinary People}

The widespread participation of ordinary local people in mass violence took place in settings as diverse as Cambodia (Hinton 2005), eastern Europe (Gross 2001; 2016; Bartov 2018), Indonesia (Dwyer \& Santikarma 2003), and Rwanda (Fujii 2009). There are several distinct micro-level dynamics that motivate ordinary people to attack and kill their neighbors who happen to be members of another group. I briefly summarize each of these mechanisms to generate specific hypotheses.

Greed

People can participate in violence for opportunistic reasons (e.g., looting) when costs of doing so are low (i.e., acting with impunity against defenseless victims) and tangible benefits are substantial (Collier \& Hoeffler 1998; Mueller 2000). In the Holocaust, non-Jewish populations of Eastern Europe seized properties of Jews that were killed or deported by the occupying German authorities (Charnysh and Finkel 2017). Local participation in the killing of Jews and the seizing of their properties generated a social class benefiting from the German rule (Snyder 2015, p. 185). Even after the Soviet defeat of the Nazis, this massive robbery of property was not challenged and became a point of contact between the communist system and local populations (p. 285).

Greed hypothesis: Members of a group attack members of a religious out-group primarily for material gain.

\section{Threat}

\footnotetext{
${ }^{5}$ The situational approach to the study of violence suggests that certain circumstances characterized by tension and fear rather than background explanations (i.e., cultural prejudices) explain its outbreak and intensity (Zimbardo 2007; Collins 2008). This approach is less insightful when it comes to the reasons why a non-threatening ethnic group (and not others) becomes a primary target of violence in the first place.
} 
Straus (2006) argues that the main drivers of Rwandan genocide were not ideological beliefs or preexisting ethnic antipathy but wartime uncertainty and the perception of existential threat to the group fueling fear. Under these conditions, social pressures made it less costly to comply with those who demanded acts of killing than non-compliance with these demands. While mutual fear polarizes societies, material and structural opportunities translate this fear into violence (McDoom 2012). Other scholars offer rationalist models of fear to explain ethnic violence in the wake of state collapse (Posen 1993). In the absence of state control, ethnic groups face a security dilemma: since no groups can trust others not to arm, self-defense efforts of each group increases the insecurity of others. When faced with the possibility of future attack, it would be in the best interest of a group to strike first.

Threat Hypothesis: Members of a group attack members of religious out-group because they fear an attack from them.

\section{Resentment}

Petersen (2002, p. 51) defines resentment as "the intense feeling that status relations are unjust combined with the belief that something can be done about it." ${ }^{6}$ It is primarily about perceived political subordination of a majority group by a minority group. Building on this conceptualization, it is useful to rely on two primary dimensions of societal relations shaping how members of a group develop stereotypes of members of another group: competence and warmth (Fiske et al. 2002). While the former concerns the perceived abilities and merits of a group (i.e., how competitive they are), the latter is about the perceived distance between the two groups. Groups perceived to have low competence but high warmth (e.g., elderly) generate emotions of pity (i.e., paternalism); groups perceived to have high competence and warmth (e.g., black professionals in the U.S.) generate admiration; groups perceived to have low competence and warmth (e.g., welfare recipients and poor blacks in the U.S.) generate contempt and disgust; groups perceived to have high competence but low warmth (e.g., Jews, Chinese in Indonesia) generate envy that is the basis of resentment. Changing socio-economic and political dynamics may "alter groups' relative status and interdependence" (p. 899) and result in shifts in emotions. In other contexts, members of a majority group can resent the increasing political presence of previously subdued minorities. For example, in Poland, pogroms were more frequent in localities where Jews were politically more assertive and demanding (Kopstein and Wittenberg 2018).

\footnotetext{
${ }^{6}$ The term, ressentiment, which is closely associated with resentment, is central to Nietzsche's critique of Christianity. Fassin (2013) alternatively conceptualizes ressentiment as an anthropological condition characterized by marginalized groups subject to deep historical injustices. In this regard, it is categorically opposed to resentment that has either no or weak historical basis.
} 
Resentment hypothesis: Members of a group attack members of a religious out-group group because they perceive the higher socioeconomic or political status of the latter as unjust.

Guilt

Snyder (2015) discusses the dynamics of local participation in the mass violence against the Jews after the German invasion of Soviet occupied part of Poland and Soviet Union in the summer of 1941. The Nazis propagated the myth of JudeoBolshevism that identified Jews as the core of power in the Soviet Union. According to this myth, the extermination of Jews would be the end of communism. Local people had no such illusions about the nature of Soviet rule. Yet they conveniently utilized the myth to detach themselves from the crumbling Soviet order with which they collaborated.

Guilt hypothesis: Members of a group attack members of another group to dissociate themselves from their past allegiances by making the latter responsible for the ancien régime.

\section{Historical Background}

Yezidis are a predominantly Kurdish speaking ethnic-religious minority. Currently, an estimated 400,000 Yezidis live in northern Iraq and Iraqi Kurdistan, 50,000 in Armenia, 10,000 in Georgia and 40,000 in Germany. Sheikh Adi bin Musafir (b. 1162) reorganized Yezidism in a way similar to monolithic religions. As Yezidism lacks an established orthodoxy and is orally transmitted across generations, most written sources about the community have been authored by non-Yezidis reflecting their biases and strategic interests (Gökçe 2012). The Peacock Angel, the highest of the seven angels ruling the world, is central to Yezidi faith and perceived to be God's enabler in the world. The widespread usage of the epithet of "devil worshippers," which conflates the sacred status of Peacock Angel for Yezidis as an affront to the Muslim God, suggests that the community remained illegible for outside observers for centuries. Yezidis have a rigid hierarchical caste system of religious (sheikh and pir) and secular authorities (mîr) and their followers (murid) (Açıkyldız 2010). In practice, one's membership in these social categories is inherited from her/his parents. Marriage is endogenous and only permitted to members of one's own socio-religious group.

Mt. Sinjar has become a shelter for Yezidis who were subject to attacks by local and imperial rulers. In particular, the Ottomans, who established hegemonic control over Yezidi lands in the 16th century, organized a series of expeditions against Mt. Sinjar primarily in order to secure caravan routes between Anatolia and Mesopotamia. In the collective memory of Yezidis, these attacks are called 'firmans'. While Yezidis were autonomous political actors with significant capacity for coalition-building, negotiation, and resistance, 
they were also subject to various attempts of forced conversion, especially in the late 19th century (Gölbaşı 2013). Yezidis continued to be marginalized in the newly established state of Iraq (Fuccaro, 1999). The Arabization policy from 1975 to the 1990 s forced Yezidis to leave their villages on Mt. Sinjar for the collective towns in the plains surrounded by Arab villagers (Dinç 2017). Becoming completely dependent on supplies and basic services provided by the government, with high rates of unemployment, poverty and illiteracy, the precarious conditions of Yezidis only grew stronger (Maisel 2008). Yezidis were also subject to a series of communal and state-led discrimination in Turkey. Under pressure from their Muslim neighbors, many of them left Turkey for Germany starting in the mid-1970s (Interview 1).

Most Yezidis fall under de facto Kurdish control after the fall of Saddam regime in 2003. The KDP (Partiya Demokrat a Kurdistanê), the main Kurdish party in Iraq, obtained greater influence in the Sinjar region than the Iraqi central government. Especially after the August 2007 attacks killing hundreds of people in two Yezidi settlements in the Sinjar, the single largest terror attack in the post-Saddam Iraq, Kurdish Peshmerga gradually took control in Sinjar. When the IS launched a coordinated attack across the Sinjar region on August 3, 2014, Peshmerga forces withdrew by showing no resistance. Local population became easy prey for the IS. Those captured either were executed or enslaved; the ones who could take refuge on Mt. Sinjar tried to survive for days in the most agonizing conditions. At least 1,500 Yezidis were executed; almost 1,500 died on Mount Sinjar from dehydration or starvation. Around 6,800 were kidnapped, mostly women and children, who were subsequently sold as slaves (Cetorelli et al. 2017). An estimated 360,00o Yezidis lived as Internally Displaced Persons (IDPs) in camps in Iraqi Kurdistan, while a further 90,ooo fled from Iraq since 2014 (Yazda 2017, p. 18). After the attacks, the Yezidi religious leadership declared that all Yezidi survivors, both males and females, remain full members of the community despite their captivity and forced conversions. ${ }^{7}$

Survivors frequently report seeing former friends, "blood brothers", "kirves" (godfathers of Yezidi boys) from nearby Sunni villages participating in killings and enslavements; helping IS carry out its attacks, kidnapping Yezidi girls and women and looting their houses (Dinç 2017). Our field research involving interviews with survivors who escaped from IS captivity also suggests a significant local participation in the massacres (e.g., Interviews $37 \& 38$ ). The complicity and cooperation of a sizeable number of local Sunni Muslims in the attacks are beyond any doubt in first person testimonies. Non-Iraqis and

\footnotetext{
${ }^{7}$ Document dated February 6, 2015 and obtained by the authors from the office of the Baba Sheikh in Sheikhan on September 27, 2017.
} 
Syrians who joined the IS from other countries also actively involved in holding Yezidi women and children captives for long periods.

\section{Research Design}

In the current political and moral climate, witnesses to and victims of violence receive widespread legitimacy and are often used to galvanize public opinion at the price of reducing complex political realities to a single emotional narrative (Fassin and Rechtman 2009, p. 194). Severals survivor Yezidi women such as Nadia Murad who were taken captive and sexually assaulted became international advocates for their community. At the same time, other survivors prefer silence and forgetfulness as a way to reestablish their lives (Erdener 2017). Regardless, many Yezidis, including the ones who were not displaced or witness of the IS attacks, continue to experience trauma. Yezidi women are more likely to be affected by PTSD and major depression (Tekin et al. 2016) and subject to exploitative journalist practices (Foster and Minwalla 2018). Cognizant of these complicated dynamics, an empirical strategy with multiple data collection efforts were pursued:

a. Dozens of in-depth interviews with Yezidi leaders, ordinary Yezidis, Kurdish policymakers, and activists and professionals working with Yezidi communities. The interviews with Yezidis captured the diversity of their experiences in terms of gender, class and status, age, location of origin, and experience of violence. Most of these interviews were being conducted in parts of Dohuk and Nineveh provinces under the Kurdish control. The interviews were primarily conducted in the Kurmanjî dialect of Kurdish, native language of most Yezidis. Other interviews were conducted via virtual means. A total of 58 face-to-face in-depth interviews as well as 10 Skype interviews were conducted as of November $2018 .{ }^{8}$ b. A systematic archival collection of documents related to Yezidi experience in multiple languages (Kurdish, Arabic, and Turkish) such as declarations by Yezidi leaders (e.g., declarations of reacceptance of Yezidi women who fled from the IS captivity into the Yezidi faith), views of Yezidis by Muslim populations and Western travelers, IS material about Yezidis (e.g., documents justifying their killings and enslavement and regulating the treatment of captured Yezidis), and statements by the Kurdish and Iraqi authorities. This archival research reveals mutual perceptions characterizing inter-religious relations.

\section{Empirical Findings}

Table 1 summarizes the five hypotheses elaborated earlier and shows how they inform different expectations about the dynamics of the IS campaign against Yezidis. I then evaluate the available evidence in the light of these expectations.

\footnotetext{
${ }^{8}$ Additional interviews were conducted by Tutku Ayhan in Iraqi Kurdistan in April-May 2019.
} 
Table 1. Explaining IS' genocidal campaign against Yezidis

\begin{tabular}{ll}
\hline \multicolumn{1}{c|}{ Mechanisms } & \multicolumn{1}{c}{ Expectations } \\
\hline Hatred & $\begin{array}{l}\text { The IS militants committed atrocities, which involved large numbers of } \\
\text { local people, against Yezidis because } \\
\text { they had deep-seated anti-Yezidi beliefs. }\end{array}$ \\
Greed & they sought material gains (i.e., seizing Yezidi properties and women). \\
Threat & $\begin{array}{l}\text { they feared Yezidis and anticipated attacks from them. } \\
\text { Resentment }\end{array}$ \\
in the post-2003 era. \\
they wanted to dissociate themselves from their past allegiances and \\
prove their loyalty to the IS.
\end{tabular}

\section{Religious Hatred}

The Yezidi community was a liminal minority who remained outside of the Ottoman moral order. Even if the Ottoman campaigns against Mt. Sinjar were often motivated by security concerns, large scale and indiscriminate violence against Yezidis were justified on religious grounds. Since they were not considered "People of the Book, they lacked the official tolerance given to Christians and Jews in the Empire. The well-known Ottoman Shaykh al-Islam Ebussuud Efendi provided an explicit justification for the killings of Yezidis in the 16th century that had been previously ignored (Hodgson 1974, p. 111). The account of Evliya Çelebi, famous Ottoman traveler, on military expedition of a local Ottoman leader on Sinjar in 17th century, carries a striking resemblance to the IS campaign in August 2017 (Çelebi 2013). He explains in detail how attackers executed, choked and burned in caves Yezidi "unbelievers" while looting their property, gold, animals; enslaving their beautiful girls and boys.

Religious considerations became even more central to how the Ottoman state dealt with Yezidis during the reign of Abdülhamid II in the late 19th century. Yezidis were classified as a group whose "deviant" religious beliefs foster rebelliousness. ${ }^{9}$ The project of making loyal subjects out of Yezidis involved systematic attempts at their conversion at a

\footnotetext{
${ }^{9}$ According to a common view, Yezidis were originally followers of the second Umayyad Caliph Yazid bin Muaviye and split from Islam (Okçu 1993; Teymûr 2008, p. 64). An edict issued by Ali Pasha, the Ottoman governor of Baghdad in the first decade of the $19^{\text {th }}$ century, declared them apostates (mürted) to justify his campaign against Yezidis based in Mt. Sinjar (Abca 2006, pp. 179-80).
} 
time when increasing presence of foreign representations and missionaries in the region aggravated the threat perception of the Ottoman state (Gölbaşı 2013). The conscription of Yezidis would facilitate their Islamization, and make them immune to the appeal of foreign influences, and ensure their loyalty to the Ottoman order. In 1892, an Ottoman pasha entrusted with the task of dealing with the "Yezidi question" engaged in a campaign of terror and destruction. Hundreds of Yezidis were killed, the Lalish, the spiritual center of Yezidis, was converted to a madrasa, sacred religious objects were confiscated, mosques were built in Yezidi villages, leading figures of the community were forced to convert. Even if the campaign failed to achieve its goal and the pasha was recalled, the Ottoman continued to perceive Yezidis as "devil worshippers" unqualified for an official recognition of their beliefs (Gökçe 2013).

The IS view of Yezidis is consistent with these historical views propagated by representatives of Orthodox Islam. An article in October 2014 issue of Dabiq, an English-language magazine published by the IS, explicitly explains the rationale of attacking, killing, and enslaving Yezidis..$^{10}$ It describes Yezidis as a "pagan minority" whose continuing existence is something for which God will judge Muslims. The article clearly shows that IS differentiates among People of the Book (i.e., Christianism or Judaism), apostate groups that were originally Muslim, and religious groups that were "originally polytheistic" and subject to forced conversion and enslavement even if they did not fight against Muslims. These interpretations are justified on grounds of being compatible with the majority opinion among Muslim clergy. While leading Muslim authorities condemned the IS violence against the Yezidis in 2014, they did not address the presence of pejorative Yezidi beliefs among Orthodox Islamic sources.

The IS violence against Yezidis was more intense than its violence against other groups. Although the IS attacked other minority groups such as Christians, Shabaks, Kaka'is and Shiite Turkmens, the scale of executions and kidnapping targeting these groups were significantly lower. According to an official person actively involved in the saving of individuals kidnapped by the IS, there were only 14 cases of Christians being liberated as

\footnotetext{
${ }^{10}$ The article is titled "The Revival of Slavery before the Hour" (pp. 13-7). The issue of Dabiq released in May 2015 also contains an article justifying the practice of slavery against enemies.

${ }^{11}$ The Shiite clerical views of Yezidis exhibit some variation. In response to a written question about the Yezidis submitted online to the office Ayatollah Ali Khameni, the Supreme Leader of the Islamic Republic of Iran, implied that Yezidis are infidels and not People of the Book (response received from www.khameni.ir on October 27, 2017). The office of Ayatollah Makarem Shirazi, a high ranking Iranian Shiite cleric, defined Yezidism as an ancient pre-Islamic Kurdish religion and suggested that they should be avoided in general (response received from www.makarem.ir on October 29, 2017). The office of Ayatollah Bayat Zanjani, a high ranking cleric known for his reformist tendencies, responded by saying that we should treat others humanely as suggested by Islamic ethics (response received from www.bayat.info on November 6, 2017).
} 
opposed to 3,288 cases of Yezidis as of May 2018 (Interview 55). Similarly, interviewees reported that "the IS told Christians in Mosul to leave." Yezidis also expected a chance to leave, which was not given (Interviews $7 \& 11$ ). Another respondent mentioned that the IS attack in Tal Afar, a city west of Mt. Sinjar, against Shiites did not reach such high and intense levels of violence as in the case of Yezidis, in part due to Shiites leaving in advance but also because of the fact that the IS did not accept Yezidism as a celestial religion (Interview 6). "Christians [in Mosul] who chose not to convert were allowed to leave because ISIS considers them 'People of the Book.' Yezidis assumed ISIS would allow them to do the same" (Khalek, 2017).

Petersen (2002) suggests that if the target of violence is a group that has frequently been attacked with similar justification over an extended time period, hatred could be a strong motive. As summarized above, there is a long history of attacks against Yezidis on religious grounds (Moradi \& Anderson, 2016). At the same time, one cannot simply assume that local people subscribe to a religious ideology of hatred propagated by political and religious leaders on orthodox teachings. ${ }^{12}$ It could be possible that local perceptions of Yezidis could significantly deviate from that of Orthodox Islam.

The orthodox Islamic view of Yezidis as "devil worshippers" has resonated at the local level as many ordinary Muslims perceived Yezidis as a community following the personification of evil (Savelsberg et al. 2010). For instance, Yezidis in Turkey had many pejorative names in addition to devil worshippers including "infidels," "enemies of Ali, the son-in-law of Prophet Mohammad," "the ones with eight moustaches," and "unbelievers" (Çakar 2007, p.7). A scholar conducting fieldwork in Iraqi Kurdistan in 1992 observed that both Christian and Muslim communities had prejudicial beliefs about Yezidi neighbors (Allison 2001, p. 37). Such pejorative views continue to persist. A leading member of the Yezidi community remarked that a majority of people still perceive Yezidis as devil worshippers (Interview 49). Many Yezidis from Sinjar who survived the attacks expressed how they had distant social relations with their Sunni neighbors who refuse to eat food cooked by Yezidis on grounds that it is not halal. Another belief common among Muslims and even Christians - is that Yezidis are filthy; they do not wash themselves (Interview 48, Allison 2001).

There is also widespread belief among Yezidis that violence against them is religiously motivated. Many of them have a cyclical view of history in sharp contrast to interpretations of history as progressive force characterized by declining role of violence in

\footnotetext{
${ }^{12}$ It is reasonable to assume that most foreign fighters who joined the IS had no prior knowledge of Yezidis. They were very likely to uncritically accept the IS view of Yezidis as "devil worshippers."
} 
human affairs (Pinker 2011). They do not necessarily perceive the IS violence as being unprecedented in their history. The vivid Yezidi oral narratives about past massacres, such as the one conducted by Mir Mohammed Kor, the chief of the Soran Emirate, in 1832 are exemplary in this regard (Eppel 2016, pp. 51-6; Dinç 2017 ). According to a Yezidi religious leader, Yezidis were targets of repeated attacks because of their religious beliefs and subject to sexual violence and forced conversions. "They took away a thousand of our girls [in 1832]. A thousand was plenty. Our population was much smaller by that time...You now see lots of Kurds around. Their fourth or fifth generation ancestors were Yezidis.” (Interview 1). Similar views were also expressed by other interviewees (Interview 34).

Many of interviewees who survived the IS violence argued that religion was the main reason behind the attacks without any hesitation. "IS came and told Muslim Arabs around us whoever kills a Yezidi deserves to go to heaven. Arabs believed that and took action. The Sinjar attack was not a political issue, it was a religious issue" (Dinç, 2017). "My son had a Muslim godfather. Not all Muslims are bad. But when ISIS came, they supported ISIS against us. It is in the ontology of Islam... [to] kill the infidels" (Interview 8). According to a survivor from the village of Kocho where the IS killed more around 380 males older than the age of 13 and enslaved elderly, women, and children on August 15, Sunni Arabs from the surrounding villages actively took part in the assault (Interview 2). A male survivor from the same village narrated that the decision to execute males and enslave women and children came after their refusal to convert to Islam en masse. Most of the attackers were Sunni Muslims from neighboring villages whom people of Kocho used to invite to their weddings (Interview 39). Another male survivor was with a group of around 100 Yezidis taken captive by the IS. They were asked to convert to Islam. Thirty-six of them expressed their desire to remain Yezidis. They were tied,blindfolded, taken away, and never heard of again. The IS forces included many local Arabs personally known to the survivor (Interview 38). Yet another survivor said, "Yezidis were weak, and they [local Sunnis] jumped on the occasion to wipe them out of the earth. Arabs found an opportunity for them to show their hatred" (Interview 8). In the aftermath of violence, Yezidis were also upset that Arab sheiks who had actively taken part in the killings few years ago freely lived in Erbil and even declared their support for Kurdish independence referendum (Interview 4). A similar observation about how religious prejudices were acted upon when the opportunity arose was expressed by a survivor. "When ISIS came to Shingal, they thought that the Caliphate came. They took the opportunity. Before, they were not so powerful to attack Yezidis.” (Interview 54).

Fujii suggests that people rarely act as ethnic blocks in times of conflict and local relations and power structures shape the dynamics of participation in violence (2008, 
p.570). Consistent with this insight, not all local Sunni communities participated in violence against Yezidis. For instance, members of the Sunni Arab Shammar tribe inhabiting the border town and surroundings of Rabia, located in the northwestern part of the Mt. Sinjar, did not attack Yezidis. They were supportive of the post-2003 order unlike the rest of the Sunni Arabs in the Sinjar area and fought against Salafi jihadist groups including both $\mathrm{Al}$-Qaeda and the IS (Interview 46) ${ }^{13}$ Yet, members of the same tribe residing in southern Sinjar were actively involved in the attacks including mass executions and kidnappings of Yezidis (Acaj 2016, pp. 95-6). In fact, an overwhelming majority of mass graves of Yezidis were discovered in southern part of Mt. Sinjar. Out of 36 mass graves identified by a Yezidi NGO, 29 of them were located in the south (Yazda 2018).

A local Yezidi researcher suggested that Saddam's Faith campaign, which was officially announced in 1993 (Baram 2011; Helfont 2018), had a transformative effect among communities around Mosul such as Ba'aj (south of Sinjar) and Tal Afar. Especially in mixed religious areas, Salafi beliefs and norms disseminated among local Sunni population. The newer generation of Arabs were not compliant with local customs of coexistence and developed sharpened attitudes toward Yezidis (Interview 41). After the fall of Saddam in 2003, Al-Qaeda achieved a resilient social base in areas south and east of Mosul (Interview 45). Tal Afar emerged as one of the hubs of Salafi-jihadism in post-2003 Iraq (Ylldız 2017). It can be argued Salafi beliefs that are categorically intolerant of Yezidis disseminated unevenly in more recent periods. While these beliefs have "ancient" origins, their influence at the local levels reflects changing political circumstances. ${ }^{14}$ Overall, the perception of Yezidis as a liminal minority greatly facilitated local participation in the atrocities including mass killings and enslavements.

\section{Greed}

Yezidis, especially those living in Sinjar area, have remained one of the most disadvantaged groups in Iraq. A Yezidi politician resembled Sinjar to Darfur region of Sudan given its underdevelopment in comparison to other areas inhabited by Yezidis (Interview 41). Yezidis in Sinjar were mostly uneducated and unemployed, working in agriculture for very low wages or doing construction work or other 'low prestigious' jobs (Savelsberg et al. 2010). There was an improvement in the material well-being of Yezidis in Sinjar in the post-2003 era (Spät 2018, p. 4). Some Yezidis, especially the ones serving in the Iraqi army or working for the

\footnotetext{
${ }^{13}$ The first post-Saddam president of Iraq, Ghazi Mashal Ajil al-Yawer, was a head of the Shammar tribe.

${ }^{14}$ This finding is similar to Kaufman (2001, p. 12) who suggests that while ethnic hatreds motivate members of a group to commit atrocities against members of another group, they are modern products renewed across generations by myths and symbols.
} 
U.S. army after 2003 built themselves houses and purchased cars (Dinç 2017). Nonetheless, Yezidis did not necessarily achieve a higher socioeconomic status in comparison to local Sunni Arabs.

There is plenty of evidence that attackers did not only kill and enslave Yezidis but also robbed them. In the Kocho massacre on August 15, 2014, victims were asked to surrender their cash and valuable items. Most importantly, kidnapped Yezidi became properties of their captors. Yezidi women were repeatedly raped and employed in various chores. Children were brainwashed and trained as soldiers for the IS. Even some Yezidi men became forced labor for IS and its supporters as shepherds and manual workers. In cases when local Sunnis helped Yezidis, material motives were also predominant. Many of them asked for a significant amount of ransom to release Yezidi women (Interview 26). "Some tribes helped ISIS. Some helped Yezidis, others helped Yezidis, but still took their money.” (Interview 53).

Yet the predominant motive seems far from being mainly economic or sexual benefits. Most importantly, the IS and local collaborators prey on Yezidi women because they were Yezidis. When they had the opportunity to do so, They did not kidnap non-Yezidi women in large numbers (i.e., Christians in Mosul), who were often given the option of leaving. Furthermore, the greed hypothesis cannot explain by itself the cases in which attackers simply destroyed Yezidi houses, without taking any single belonging for themselves (Dinç 2017).

\section{Threat}

Sunni Arabs lost their status and political influence with the fall of the Ba'th rule. Their widespread participation in insurgencies resulted in massive retaliatory violence by the occupying U.S. forces, the Iraqi army, and Shiite armed groups. In Sinjar, there was initially a period of uncertainty. In the words of a Sunni Kurd from the area, "After 2003, everyone [Arabs, Kurds, Yezidis] was suspectful of each other [in Sinjar], not sure about other's intention" (Interview 67). In the subsequent years, especially after 2007, however, political and military control gradually passed from Sunni Arabs to Sunni Kurds after 2003. Not surprisingly, the Sunni Arab community faced very high levels of threats. The rise of the IS as a potent force provided a degree of security and order for segments of the Sunni Arab community in the face of sectarian policies pursued by the Iraqi government (Gerges 2016).

However, Yezidis did not present a threat to the status and security of Sunni Arabs and Kurds given their small demographic size, weak economic status, political fragmentation and underrepresentation, and, unlike Christians, lack of strong international linkages.

Furthermore, Yezidis did not assault the sacred values of Sunni Islam by occupying their holy places or denying the legitimacy of their beliefs. While Yezidis achieved political positions in 
Sinjar including the district governorship, the real power was in the hands of the KDP. According to a leading member of the Yezidi community, Yezidis are underdogs with no real political leverage in Iraq (Interview 49). Moreover, a substantial number of Yezidis explicitly claimed that their lives were more secure under the Saddam's dictatorship (e.g., Interview 39). So there is basically no evidence for the threat hypothesis given the continuing status of Yezidis as a politically and militarily weak group.

\section{Resentment}

In the eyes of Sunni Muslims, Yezidis has always been a distant group (low warmth) with low status (lacking competence). At the same time, the 2003 invasion diminished the status of Sunni Arabs while generated opportunities for Yezidis who became a crucial demographic bloc to the Kurdistan Regional Government (KRG)'s claims over disputed territories and its power politics in the Nineveh province, one of the most contested areas in the entire country. In the 2005 referendum on the new Iraqi constitution, around 55 percent of the voters in the Nineveh province that also includes Sinjar said "no." It can be inferred that Yezidis' support for the constitution was a key factor that the no votes remained short of a two-thirds majority that would have resulted in the defeat of the new constitution. ${ }^{15}$ Yet a significant number of Yezidis were uncomfortable with the ethnic polarization. They were fearful that their community was becoming pawns in the Kurdish-Arab territorial struggle and characterized the KRG policies as "Kurdification” of Sinjar (UNAMI 2009).

These developments generated resentment among the Sunni Arabs and Turkomans in the area who lost their privileged positions and increasingly perceived the Yezidis as being part of the Kurdish power structure (Interview 45). In the words of a survivor, "[u]ntil IS came, we were powerful. After Peshmerga took control of the Sinjar, they established checkpoints and kept Arabs waiting long time at these points. Those Arabs started having hostility against Peshmerga and against us.” (Dinç 2017). “After 2003, the KDP was more powerful in Sinjar...They gave salaries to some families. Financially, it was very good for a short term, we got really prosperous. After 2003, we [Yezidis] stopped working for Arabs, we came to work for Kurds" (Interview 54). "When Kurds entered Sinjar, Arabs started hating us" (Interview 66). Overall, local Sunni Arabs resented the rising power of Sunni Kurds affiliated with the KDP in Sinjar and targeted Yezidis who were perceived to benefit from the KDP patronage. A Yezidi politician pointed out that given the highly contested nature of

\footnotetext{
${ }^{15}$ For the defeat of the constitution, at least three provinces would have to vote no with a two-thirds majority. That threshold was passed in Anbar and Salah-a-din, the two Sunni Arab dominated provinces.
} 
elections in Nineveh, purging Yezidis out of Sinjar in 2014 tilted the demographic balance in favor of Sunni Arabs (Interview 25).

There are three limitations of the resentment argument. First, it cannot explain Sunni Kurds' participation in the attacks. Several Kurdish tribes, including the Qabousi, reportedly killed Yezidi men and enslaved Yezidi women (Interview 65). Next, Yezidis who remained beyond the patronage of KDP and other parties also became targets of violence. There is no evidence that the IS supporters discriminated between Yezidis on the basis of their political affiliation, a pattern that was prevalent during the Saddam years. Finally, resentment by itself falls short of explaining the full repertoire of the IS violence including the abduction of children and sexual enslavement of women. IS fighters executed non-combatant members of other groups during its advances, yet it did not engage in such systematic sexual violence and forced conversion targeting any other groups.

\section{Guilt}

Many Sunni Arabs including communities in the Sinjar area benefited from and actively supported the Saddam regime. After 2003, they experienced a huge reversal in their fortunes. As in some other contexts such as eastern Europe at the time of Nazi invasion in 1941, local communities affiliated with a fallen regime may participate in mass atrocities against a minority to vindicate themselves in the eyes of the new rulers. However, the new political order in Iraq following the U.S. invasion in 2003 did not necessarily identify Yezidis as a minority supportive of the ancien régime. While the security of Yezidis deteriorated after 2003, the attacks came from Sunni extremists and not from Shiite groups that dominate politics in the post-Saddam era. Furthermore, Yezidi violence was condoned by neither Shiite nor Kurdish authorities. So there is no evidence that local Sunnis attacked Yezidis to align themselves with the new order. ${ }^{16}$

\section{Concluding Remarks}

This paper develops a novel theoretical argument about the vulnerability of certain types of minorities to religiously justified and motivated violence. It also offers a micro-level research design distinguishing among different mechanisms characterizing the motives of perpetrators of violence against members of a religious out-group. This approach helps us

\footnotetext{
${ }^{16}$ Some Sunni Kurds suggested that Yezidis who initially escaped returned because they trusted false promises of former Ba'th members they knew. "Saddam forced Yezidis to come down the mountain and live in collective responsibility. He gave them salaries and food in exchange for their support. Yezidis then got lazy, they started doing nothing. During IS' attack, some people in Kocho thought that it was Saddam's men, that's why they didn't leave" (Interview 67). This reasoning could be interpreted as "blaming the victim" and aims to serve to minimize Kurdish responsibility in leaving Yezidis unprotected.
} 
better the historical puzzle of the IS violence against Yezidis, a liminal minority with a long-history of marginalization. The IS's particularly vicious treatment of Yezidis could not be explained without a reference to its religious ideology that builds on centuries-old orthodox Islamic perceptions of Yezidis. At the societal level, anti-Yezidi norms and beliefs were necessary both for making extreme levels of violence possible and permissible and for mobilizing local population to participate in the atrocities. The IS's ability to capitalize on preexisting anti-Yezidi hatred among the local society was a necessary factor in its ability to mobilize active popular involvement in its genocidal campaign. Furthermore, without such norms and beliefs, violence against Yezidis would have remained more constrained in terms of both repertoire (i.e., extreme levels of sexual violence) and frequency (i.e., executions and kidnappings of thousands).

To put it bluntly, while "ancient hatreds" transmitted unchallenged across generations do not directly foster mass violence, they provide a fertile ground for the feasibility of campaigns targeting historically stigmatized minorities when the opportunity arises. Religious teachings and norms are not really ambivalent regarding these liminal minorities. An important implication is that policies and initiatives aiming to transform exclusionary beliefs and norms at both theological and popular levels are essential for the sustainability of ethnic and religious pluralism in contemporary times. In this regard, it is also important to identify the conditions under which members of a group help members of another group under threat. While large numbers of local Sunnis participated in the killing and enslavement of Yezidis, others actually risked their lives to help their neighbors. As in other genocidal contexts, human altruism and viciousness coexisted.

\section{References}

Abca, Y. (2006). Yezidilik ve Osmanl yönetiminde Yezidiler. MA Thesis. Eskişehir Osmangazi University.

Acaj, I (2016). Hujum Daesh ali Shangal. In Karithat Shangal: Majmuat Bhuth wa Dirasat. Duhok: Hawar.

Allison, C. (2001). The Yezidi Oral tradition in Iraqi Kurdistan. Curzon Press, 2001.

Baram, A. (2011). From militant secularism to Islamism: the Iraqi Ba'th regime 1968-2003. Woodrow Wilson International Center for Scholars Occasional Paper.

Bartov, O. (2018). Anatomy of a genocide: the life and death of a town called Buczacz. New York: Simon \& Schuster.

Bowles, S. (2008). Conflict: altruism's midwife. Nature 456: 326-7.

Brubaker, R. (2015). Religious dimensions of political conflict and violence. Sociological

Theory, 33, 1-19. 
Bushman, B. J., Ridge, R. D., Das, E., Key, C. W., \& Busath, G. L. (2007). When God sanctions killing: Effect of scriptural violence on aggression. Psychological Science 18, 204-7.

Cetorelli, V., Sasson I., Shabila N., and Burnham, G. (2017). Mortality and kidnapping estimates for the Yezidi population in the area of Mount Sinjar, Iraq. PLoS Medicine 14(5), 1-15.

Chandra, K. (2006). What is ethnic identity and does it matter?. Annual Review of Political Science, 9: 397-424.

Charnysh V. \& Finkel, E. (2017). The death camp Eldorado: political and economic effects of mass violence. American Political Science Review, 11(4), 801-18.

Choi, J., \& Bowles, S. (2007). The coevolution of parochial altruism and war. Science 318: 636-40.

Chua, A. (2018). Political tribes: group instincts and the fate of nations. New York: Penguin Press.

Collier, D. (2011). Understanding process tracing. PS: Political Science and Politics 44: 823-30.

Collier, P., \& Hoeffler, A. (1998). On economic causes of civil war. Oxford economic papers, $50(4), 563-73$.

Collins, R. 2008. On violence: A micro-sociological theory. Princeton, NJ: Princeton University Press.

Çakar, M. S. (2007). Yezidîlik: tarih ve metinler - Kürtçe ve Arapça nüshaları. Ankara: Vadi Yayınları.

Çelebi, E. (2013). Günümüz Türkçesiyle Evliyâ Çelebi Seyahatnâmesi, 1, 1-6. Kitaplar, eds. Seyit Ali Kahraman, Yücel Dağlı. İstanbul: Yapı Kredi Yayınları.

Davis, N. Z. (1959). The rites of religious violence: religious riot in sixteenth century France. Past and Present 59, 51-91.

Dinç, N. K. (2017). Ezidilerin 73. fermanı: Şengal soykırımı, İstanbul: Zan Vakfı.

Dwyer, L. and Santikarma, D. (2003). 'When the world turned to chaos' 1965 and its aftermath in Bali, Indonesia. In The specter of genocide: mass murder in historical perspective, eds. R. Gellately and B. Kiernan. New York: Cambridge University Press, 289-306.

Engels, F. (1926). The Peasant War in Germany (originally published in 1850). International Publishers.

Eppel, M. (2016). A People without a state: The Kurds from the rise of Islam to the dawn of nationalism. Austin: University of Texas Press. 
Erdener, E. (2017). The ways of coping with post-trauma of Yezidi refugee women in Turkey. Women's Studies International Forum, 65, 60-70.

Fassin, D., and Rechtman, R. (2009).The Empire of Trauma: An Inquiry into the Condition of Victimhood. Princeton: Princeton University Press.

Fassin, D. (2013). On Resentment and Ressentiment: The Politics and Ethics of Moral Emotions. Current Anthropology 54(3), 249-67.

Fehr, E. \& Gächter, S.(2002). Altruistic punishment among humans. Nature 415, 137-40.

Fiske, S. T., Cuddy, A. J., Glick, P., \& Xu, J. (2002). A model of (often mixed) stereotype content: competence and warmth respectively follow from perceived status and competition. Journal of personality and social psychology, 82(6), 878-902.

Foster J. E., \& Minwalla S. (2018). Voices of Yezidi women: perceptions of journalistic practices in the reporting on ISIS sexual violence. Women's Studies International Forum, 67, 53-64.

Fuccaro, N. (1999). Communalism and the state in Iraq: the Yezidi Kurds, c. 1869-1940. Middle Eastern Studies, 35(2), 1-26.

Fujii, L. A. (2008). The power of local ties: popular participation in the Rwandan genocide. Security Studies, 17(3), 568-97.

Fujii, L. A. (2009). Killing neighbors: webs of violence in Rwanda. New York: Cornell University Press.

Gerges, I. (2016). ISIS: A history. Princeton, NJ: Princeton University Press.

Gökçe, A. (2012). Osmanlı ve İngiliz Arşiv Belgelerinde Yezidiler. İstanbul: Bilgi Üniversitesi Yayınları.

Gökçe, A. (2013). Ed. Abede-i İblis: Yezidi Ta’îfesinin İtikadat, A’dâtı, Evsafi. İstanbul: Bilgi Üniversitesi Yayınları.

Gölbaşı, E. (2013). Turning the "Heretics" into loyal Muslim subjects: Imperial anxieties, the politics of religious conversion, and the Yezidis in the Hamidian Era. The Muslim World, 103(1), 3-23.

Greene, J. (2014). Moral tribes: emotion, reason, and the gap between us and them. New York: Penguin.

Gross, J. 2001. Neighbors: the destruction of the Jewish community in Jedwabne, Poland. Princeton, NJ: Princeton University Press.

Gross, J. 2016. Golden harvest: events at the periphery of the Holocaust. New York: Oxford University Press.

Grossman, D. (2014). On killing: the psychological cost of learning to kill in war and society. Open Road Media. 
Grzymala-Busse, A. (2016). The difficulty with doctrine: how religion can influence politics. Government and Opposition, 51(2), 327-50.

Gutiérrez-Sanín, F., \& Wood, E. J. (2017). What should we mean by "pattern of political violence"? repertoire, targeting, frequency, and technique. Perspectives on Politics, 15(1), 20-41.

Haidt, J. (2012). The righteous mind: why good people are divided by politics and religion. New York: Vintage Books.

Hassner, R. E. (2009). War on Sacred Grounds. Ithaca, NY: Cornell University Press.

Hayden, R. M. (1996). Imagined communities and real victims: self-determination and ethnic cleansing in Yugoslavia. American Ethnologist, 23(4), 783-801.

Helfont, S. (2018). Compulsion in religion: Saddam Hussein, Islam, and the roots of insurgencies in Iraq. New York: Oxford University Press.

Hinton, A. L. 2005. Why did they kill? Cambodia in the shadow of genocide. Berkeley and Los Angeles, CA: California University Press.

Hodgson, Marshall G. S. (1974). The Venture of Islam Vol III. The gunpowder empires and modern times. Chicago: University of Chicago Press.

Horowitz, M. (2009). Long time going: religion and the duration of crusading. International Security 34: 162-93.

Johnson, M. K., Rowatt, W. C., \& LaBouff, J. P. (2012). Religiosity and prejudice revisited: In-group favoritism, out-group derogation, or both? Psychology of Religion and Spirituality, 4(2), 154-68.

Juergensmeyer, M. (2009). Global religion: religious challenges to the secular state, from Christian militias to al Qaeda. Berkeley, CA: University of California Press.

Kaufman, S. J. (2001). Modern hatreds: The symbolic politics of ethnic war. Ithaca, NY: Cornell University Press.

Khalek, R. (2017). Genocide in Iraq: When Local Sunni Became ISIS and Slaughtered Their Neighbors. Grayzone Project, Alternet.

Kopstein, J. S., and Wittenberg, J. (2018). Intimate violence: anti-Jewish pogroms on the eve of the Holocaust. Ithaca, NY: Cornell University Press.

LaBouff, J. P., Rowatt, W. C., Johnson, M. K., \& Finkle, C. (2012). Differences in attitudes toward outgroups in religious and nonreligious contexts in a multinational sample: A situational context priming study. International Journal for the Psychology of Religion, 22(1), 1-9.

Lange, M. 2017. Killing others: A natural history of ethnic violence. Ithaca, NY: Cornell University Press. 
Livingstone, D. (2011). Less than human: Why we demean, enslave, and exterminate others. New York: St. Martin's Press.

Maisel, S. (2008). Social change amidst terror and discrimination: Yezidis in the new Iraq. The Middle East Institute Policy Brief 18, 1-9.

Mamdani, M. 2001. When victims become killers: colonialism, nativism, and the genocide in Rwanda. Princeton, NJ: Princeton University Press.

Mann, M. (2005). The Dark side of democracy: explaining ethnic cleansing. New York: Cambridge University Press.

McDoom, O. S. (2012). The psychology of threat in intergroup conflict: emotions, rationality, and opportunity in the Rwandan genocide. International Security, 37(2), 119-55.

McKay R., Efferson, C., Whitehouse, H., \& Fehr, E. (2010). Wrath of God: religious primes and punishment. Proceedings of the Royal Society B: Biological Sciences, 278(1713), 1858-63.

Moradi, F., \& Anderson, K. (2016). The Islamic State's Êzîdî genocide in Iraq: the Sinjār operations. Genocide Studies International, 10(2), 121-38.

Mueller, J. (2000). The banality of “ethnic war”. International Security, 25(1), 42-70.

OHCHR (Office of the United Nations High Commission for Human Rights) (2016). "They Came to Destroy:" ISIS Crimes against the Yezidis. A/HRC/32/CRP.2.

Okçu, Davut. (1993). İslamdan Ayrlan Cereyanlar: Yezidilik ve Yezidiler. Van: N.P.

Petersen, R. D. (2002). Understanding ethnic violence: fear, hatred, and resentment in twentieth-century Eastern Europe. Cambridge University Press.

Pinker, S. (2011). Better angels of our nature: why violence has declined. New York: Viking.

Posen, B. (1993). The security dilemma and ethnic conflict. In M. E. Brown (Ed.), Ethnic conflict and international security (pp. 103-124). Princeton, NJ: Princeton University Press.

Pyszczynski, T., Abdollahi, A., Solomon, S., Greenberg, J., Cohen, F., \& Weise, D. (2006). Mortality salience, martyrdom, and military might: The great Satan versus the axis of evil. Personality and social psychology bulletin, 32(4), 525-537.

Sapolsky, R. (2017). Behave: the biology of humans at our best and worst. New York: Penguin.

Savelsberg, E., Siamend H., \& Irene D. (2010). Effectively urbanized: Yezidis in the collective towns of Sheikhan and Sinjar. Études Rurales, p. 101-16.

Scott, J. C. (1998). Seeing like a state: how certain schemes to improve the human condition have failed. New Haven: Yale University Press. 
Shariff, A. F., \& Norenzayan, A. (2007). God is watching you: priming God concepts increases prosocial behavior in an anonymous economic game. Psychological science, 18(9), 803-9.

Simon-Skjodt Center for the Prevention of Genocide. (2015). "Our Generation is gone." The Islamic State's targeting of Iraqi minorities in Ninewa. Bearing Witness Trip Report.

Snyder, T. (2015). Black earth: the Holocaust as a history and warning. New York: Tim Duggan.

Spät, E. (2018). Yezidi identity politics and political ambitions in the wake of the ISIS attack. Journal of Balkan and Near Eastern Studies, 20(5), 420-38.

Stark, R. and Finke, R. (2000). Acts of faith: explaining the human side of religion. Berkeley: University of California Press.

Straus, S. (2006). The order of genocide: race, power, and war in Rwanda. Cornell University Press.

Suny, R. G. (2015). "They can live in the desert but nowhere else": a history of the Armenian Genocide. Princeton University Press.

Tekin, A., Karadă̆, H., Süleymanoğlu, M., Tekin, M., Kayran, Y., Alpak, G., \& Şar, V. (2016). "Prevalence and gender differences in symptomatology of posttraumatic stress disorder and depression among Iraqi Yezidis displaced into Turkey.” European Journal of Psychotraumatology, 7(1), 1-8.

Teymûr, A. (2008). Arab kaynaklarına göre Yezidiler ve Yezidiliğin doğuşu. İstanbul: Ataç. Tezcür, G. M (2016). Ordinary people, extraordinary risks: participation in an ethnic rebellion. American Political Science Review, 110(2), 247-64.

Toft, M. D. (2003). The geography of ethnic violence. Princeton, NJ: Princeton University Press.

Toft, M. D. (2013).Religion and political violence. In The Oxford Handbook of Religion and Violence (pp. 1-9). Oxford University Press.

United Nations Assistance Mission for Iraq (UNAMI) (2009). District analysis summary: Sinjar district and Qahtaniya sub-district. Unpublished Report.

Weitz, E. D. (2015). A century of genocide: Utopias of race and nation. Princeton University Press.

Wimmer, A. (2013). Waves of War: Nationalism, State Formation, and Ethnic Exclusion in the Modern World. New York: Cambridge University Press.

Yazda (2017). An Uncertain Future for Yezidis: A Report Marking Three Years of an Ongoing Genocide. 
Yazda (2018). Working against the Clock: Documenting Mass Graves of Yezidis Killed by Islamic State.

Yıldız, T. (2017). Mezhep Çatışmasına Bir Etnik Grup ve Yerel Bağlam Üzerinden Bakmak: Irak Türkmenleri ve Telafer Örneği. Türkiye Ortadoğu Çalsşmaları Dergisi, 4(2), 41-73.

Zimbardo, P. 2007. The Lucifer effect: understanding how good people turn evil. New York: Random House. 


\section{Appendix}

Table A.1. The list of Interviews (face-to-face unless stated otherwise)

Interview Interviewee, Location \& Date

Researcher

Number

\begin{tabular}{|c|c|c|}
\hline Interview 1 & $\begin{array}{l}\text { Yezidi community leader, Berlin, June 28, } 2017 \text { (migrated to } \\
\text { Germany in 1973). }\end{array}$ & GMT \\
\hline Interview 2 & $\begin{array}{l}\text { Yezidi female survivor, Berlin, June 30, } 2017 \text { (originally from } \\
\text { the village of Kocho, Sinjar). }\end{array}$ & GMT \\
\hline Interview 3 & $\begin{array}{l}\text { Yezidi religious leader, Sheikhan, Iraqi Kurdistan, } \\
\text { September 27, } 2017 .\end{array}$ & GMT \\
\hline Interview 4 & $\begin{array}{l}\text { Yezidi religious and community leaders, Lalish, Iraqi } \\
\text { Kurdistan, September } 28,2017 .\end{array}$ & GMT \\
\hline Interview 5 & Camp official, Mam Rash IDP Camp, September 28, 2017 & GMT \\
\hline $\begin{array}{l}\text { Interview } 6 \\
(S K Y P E)\end{array}$ & $\begin{array}{l}\text { Kurdish male based in Turkey who conducted interviews } \\
\text { with Yezidis in camps, October 22, } 2017 .\end{array}$ & TA \\
\hline $\begin{array}{l}\text { Interview } 7 \\
\text { (SKYPE) }\end{array}$ & $\begin{array}{l}\text { Kurdish male social scientist based in Dohuk, Iraqi } \\
\text { Kurdistan, October 24, } 2017 .\end{array}$ & TA \\
\hline $\begin{array}{l}\text { Interview } 8 \\
\text { (SKYPE) }\end{array}$ & $\begin{array}{l}\text { Yezidi male survivor based in Lincoln, Nebraska, October 28, } \\
2017 .\end{array}$ & TA \\
\hline $\begin{array}{l}\text { Interview } 9 \\
(S K Y P E)\end{array}$ & $\begin{array}{l}\text { Kurdish female based in Turkey who conducted interviews } \\
\text { with Yezidis in camps, November } 1,2017 .\end{array}$ & TA \\
\hline $\begin{array}{l}\text { Interview } 10 \\
\text { (SKYPE) }\end{array}$ & $\begin{array}{l}\text { YAZDA affiliated female researcher based in Dohuk, } \\
\text { November } 14,2017 .\end{array}$ & TA \\
\hline $\begin{array}{l}\text { Interview } 11 \\
\text { (SKYPE) }\end{array}$ & $\begin{array}{l}\text { Yezidi male survivor based in Salt Lake City, Utah, December } \\
2,2017 \text {. }\end{array}$ & TA \\
\hline $\begin{array}{l}\text { Interview } 12 \\
\text { (SKYPE) }\end{array}$ & $\begin{array}{l}\text { Yezidi male psychiatrist based in Baden-Württemberg, } \\
\text { Germany, December 5, } 2017 \text {. }\end{array}$ & TA \\
\hline $\begin{array}{l}\text { Interview } 13 \\
\text { (SKYPE) }\end{array}$ & $\begin{array}{l}\text { Two social workers, a female and male, affiliated with } \\
\text { JIYAN, an NGO in Dohuk, January 25, } 2018 .\end{array}$ & TA \\
\hline $\begin{array}{l}\text { Interview } 14 \\
\text { (SKYPE) }\end{array}$ & $\begin{array}{l}\text { Female human rights lawyer pursuing IS atrocities in Iraq } \\
\text { and Syria, based in Trinidad and Tobago, February 6-March } \\
\text { 24, } 2018\end{array}$ & GMT-TA \\
\hline
\end{tabular}


Interview 15

(SKYPE)

Interview 16

Interview 17

Interview 18

Interview 19

Interview 20

Interview 21

Interview 22

Interview 23

Interview 24

Interview 25

Interview 26

Interview 27

Interview 28

Interview 29

Interview 30

Interview 31

Interview 32

Interview 33

Interview 34

Interview 35

Interview 36

Interview 37
Yezidi female social worker based in York, UK, April 20,

TA 2018.

Yezidi camp media worker, Duhok, May 21,2018.

Yezidi camp director, Khanke Camp, May 22, 2018.

Yezidi school director, Khanke, May 22, 2018.

Yezidi male survivor who stayed in the hands of IS until June GMT 2016, Khanke School, May 22, 2018.

Yezidi female IDP, Khanke Camp, May 22, 2018.

TA

Yezidi female IDP, Khanke Camp, May 22, 2018.

TA

Yezidi IDP husband and wife, Khanke Camp, May 22, 2018.

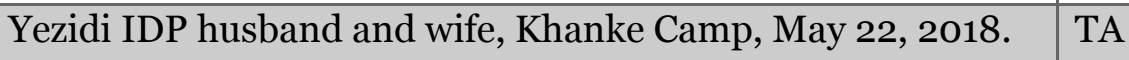

Iraqi Kurd Judge, Head of CIGE, Duhok, May 23, 2018.

Yezidi KRG Parliamentarian, Director of Lalish Foundation, $\quad$ GMT-TA

Duhok, May 23, 2018.

Yezidi activist helping women escape ISIS, Duhok, May 23, $\quad$ GMT-TA 2018.

Yezidi IDP family with two female survivors, Khanke Camp, $\quad$ GMT May 24, 2018.

\begin{tabular}{|l|l} 
Yezidi female IDP, Khanke Camp, May 24, 2018. & TA
\end{tabular}

\begin{tabular}{|l|l} 
Yezidi female IDP, Khanke Camp, May 24, 2018. & TA
\end{tabular}

Two Yezidi female survivors, Khanke Camp, May 24, 2018.

Yezidi IDP family with eleven survivors, Khanke Camp, May $\quad$ GMT $24,2018$.

Yezidi non-displaced female, Khanke, May 24, 2018.

TA

\begin{tabular}{|l|l} 
Yezidi NGO Director, scholar, Sharya Camp, May 24, 2018. & GMT
\end{tabular}

Baba Chavoush, Yezidi religious leader, based in Lalish, May $\quad$ GMT-TA $25,2018$.

Yezidi female working for EMMA Foundation, Lalish, May $\quad$ TA

$25,2018$.

Yezidi parliamentary candidate, Qadya Camp, Rawanqa,

GMT

May 26, 2018.

Yezidi male survivor who stayed under IS captivity with his

GMT 
Interview 38

Interview 39

Interview 40

Interview 41

Interview 42

Interview 43

Interview 44

Interview 45

Interview 46

Interview 47

Interview 48

Interview 49

Interview 50

Interview 51

Interview 52

Interview 53

Interview 54

Interview 55

Interview 56

Interview 57

Interview 58

Interview 59

Interview 60

Interview 61
Yezidi male survivor of Kocho massacre, Qadya Camp, Rawanqa, May 26, 2018.

Mayor of Tilkef, Malta - Duhok, May 26, 2018.

Yezidi male IDP, Khanke Camp, May 26, 2018.

PUK Shingal Representative, Duhok, May 27, 2018.

Yezidi IDP family, Sharya Camp, May 27, 2018.

KRG General, Shela, May 27, 2018.

Director of Health of Duhok Governorate, May 28, 2018.

Yezidi male consultant and expert, Duhok, May 28, 2018.

Arab male local leader, Duhok, May 28, 2018.

Yezidi female NGO worker from DAK Organization, Duhok,

May 28, 2018.

Yezidi female NGO worker from French Red Cross, Duhok, May 28, 2018.

Yezidi political leader, former Iraqi Minister, Duhok, May

GMT-TA 29, 2018.

Head of Psychology Department of Azadi Hospital in Duhok, GMT May 29, 2018.

Kurdish female psychologist at Duhok Health Department, $\quad$ TA May 29, 2018.

Former female Iraqi Minister, Duhok, May 30, 2018.

Yezidi male NGO worker from Haven Center, Sharya, May $\quad$ TA 30, 2018.

Yezidi male survivor and activist, former US army translator, $\quad$ TA Sharya, May 30, 2018.

\begin{tabular}{|l|l}
\hline Director of KRG's Rescue Office, Duhok, May 31, 2018. & GMT
\end{tabular}

\begin{tabular}{|l|l}
\hline Female Kurdish pharmacist at the head of treatment & TA
\end{tabular} program in Duhok, May 31, 2018.

Director of Health of Duhok Governorate, May 31, 2018.

GMT-TA

Yezidi female IDP, Sharya Camp, May 31, 2018.

TA

Yezidi female IDPs, Sharya Camp, May 31, 2018.

TA

Focus group with 6 female Yezidi IDPs, Sharya Camp, May

TA

31, 2018.

Yezidi journalist and consultant, Sharya, June 1, 2018.

TA 


\begin{tabular}{|c|c|c|}
\hline Interview 62 & Yezidi male IDP, Sharya, June 1, 2018. & TA \\
\hline Interview 63 & $\begin{array}{l}3 \text { Yezidi female survivors of IS captivity, Sharya, June } 1 \text {, } \\
2018 .\end{array}$ & TA \\
\hline Interview 64 & $\begin{array}{l}\text { Yezidi female NGO worker from EMMA Foundation, } \\
\text { Khanke, June } 1,2018 .\end{array}$ & TA \\
\hline Interview 65 & Yezidi male activist, Khanke Camp, June 2, 2018. & TA \\
\hline Interview 66 & Yezidi female IDPs, Khanke Camp, June 2, 2018. & TA \\
\hline Interview 67 & $\begin{array}{l}\text { Kurdish male from Sinjar, Iraqi army personnel, Duhok, } \\
\text { June 4, } 2018 .\end{array}$ & TA \\
\hline Interview 68 & Kurdish male NGO worker from GIZ, Duhok, June 5, 2018. & TA \\
\hline
\end{tabular}

